\title{
Management of celiac disease: from evidence to clinical practice
}

\author{
Tiziana M. Attardo, ${ }^{1}$ Elena Magnani, ${ }^{2}$ Carlotta Casati, ${ }^{3}$ Danilo Cavalieri, ${ }^{4}$ Pietro Crispino, ${ }^{5}$ Federica Fascì Spurio, ${ }^{6}$ \\ Stefano De Carli, ${ }^{7}$ Daniela Tirotta, ${ }^{8}$ Paola Gnerre ${ }^{9}$ \\ ${ }^{1}$ Department of Internal Medicine, Barone Lombardo Hospital, Canicattì (AG); ${ }^{2}$ Department of Internal Medicine, M. Bufalini \\ Hospital, AUSL Romagna, Cesena (FC); ${ }^{3}$ Department of Internal Medicine, Careggi Hospital, Firenze; ${ }^{4}$ School of Specialization \\ in Internal Medicine, Campus Bio-Medico University, Roma; ${ }^{5}$ Department of Internal Medicine and Emergency, Lagonegro \\ Hospital, ASP Potenza, Lagonegro (PZ); 'Department of Internal Medicine, Dell'Angelo Hospital, Asl 12 Veneziana, Mestre \\ (VE); ${ }^{7}$ Department of Internal Medicine, S. Maria della Misericordia Hospital, Udine; ${ }^{8}$ Department of Internal Medicine, Cervesi \\ Hospital, AUSL Romagna, Cattolica (RN); ${ }^{9}$ Department of Internal Medicine 2, San Paolo Hospital, Savona, Italy
}

\begin{abstract}
Celiac disease (CD) is a complex polygenic disorder, which involves genetic factors human leukocyte complex (HLA) and non-HLA genes, environmental factors, innate and adoptive immunity, and a robust chronic T-mediated autoimmune component. The main goal of the present monograph is to define a methodological approach for the disease, characterized by frequent late diagnosis, in order for the physician to become aware of the disease management, the diversity of the clinical presentation itself and in different patients. A unique attention is payed to the specific diagnostic tests to define a correct and accurate application of them, and in addition, to disease follow-up and possible complications. Moreover, a dedicated space is assigned to refractory $\mathrm{CD}$, to potential CD and non-celiac gluten sensitivity. Legislative aspects of the celiac disease in Italy are addressed, too. The celiac disease guidelines and their evaluation by means of Appraisal of Guidelines, Research and Evaluation II instrument allow us to classify the different recommendations and to apply them according to the stakeholders' involvement, pertinence, methodological accuracy, clarity and publishing independence. Finally, the most current scientific evidence is taken into account to create a complete updated monograph.
\end{abstract}

\section{Introduction}

The aims of the present review paper about celiac disease $(\mathrm{CD})$ are the following: i) to summarize physiopathological mechanisms of the disease; ii) to offer a practical tool for a correct diagnostic approach,

Correspondence: Tiziana Marcella Attardo, Department of Internal Medicine, Barone Lombardo Hospital, via Giudice Saetta 23, 92024 Canicatti (AG), Italy.

Tel.: +39.0922.733212 - Fax: + 39.0922.733395.

E-mail: claudia.fantucchio@alice.it

Key words: Celiac disease; guidelines; potential and refractory celiac disease; non-celiac gluten sensitivity; Italian legislative aspects of celiac disease.

Conflict of interest: the authors declare no potential conflict of interest.

Received for publication: 2 December 2016.

Revision received: 7 April 2017.

Accepted for publication: 4 May 2017.

This work is licensed under a Creative Commons Attribution NonCommercial 4.0 License (CC BY-NC 4.0).

CC Copyright T.M. Attardo et al., 2017

Licensee PAGEPress, Italy

Italian Journal of Medicine 2017; 11:345-359

doi:10.4081/itjm.2017.821 thanks to an in-depth knowledge of the specific tests; iii) to define a methodological approach for the disease with new accurate and integrated strategies, in order to guide the clinician to the disease diagnosis, management and assessment of refractory patients.

\section{Definition}

Celiac disease (from Greek кoเ $\lambda 1 \alpha$, abdomen, belly) is a permanent autoimmune food intolerance, which is triggered, in genetically predisposed subjects, by gluten ingestion ${ }^{1}$ of the protein wheat fraction alcohol-soluble.

The main gluten protein is gliadin, distinguished into 4 different types, based on the electrophoretic mobility $(\alpha, \beta, \gamma, \omega)$. The disease consists of an immune reaction against gluten, which mainly strikes the small intestine of the genetically predisposed subjects and usually disappears with gluten-free diet. ${ }^{2}$

In 2012 the European Society for Pediatric Gastroenterology, Hepatology and Nutrition (ESPGHAN) guidelines highlighted the $\mathrm{CD}$ definition change through the years, from a rare enteropathy to a frequent multi-organ and multi-factor disease, characterized by a genetic predisposition related to human leukocyte complex (HLA)-DQ2 and $H L A-D Q 8$ histocompatibility complex. ${ }^{3}$ Gastrointestinal (abdominal pain, constipation and/or diarrhea, nausea and vomit, abdominal re- 
laxation) and extra-intestinal (chronic anemia, bone demineralization with osteoporosis/osteopenia and augmented fracture risk, dental enamel defect, nervousness, fatigue, neuropathy, arthritis/arthralgia, amenorrhea, infertility, delayed puberty, height/weight defects, hepatic impairment, herpetiform dermatitis, aphthous stomatitis, etc.). ${ }^{3}$

\section{Epidemiology}

The first epidemiological reports of $\mathrm{CD}$, dating back to the 1950 s, were built on the diagnosis confirmed by symptomatic picture of malabsorption, and defined the $\mathrm{CD}$ as a rare disease almost exclusively of the childhood, with a prevalence of 1:4000 to 1:8000 in the European Countries. ${ }^{4}$ Subsequently, the paucisymptomatic or asymptomatic forms were described and, thanks to the clinical practice introduction of the serological tests, it was possible to figure out that the symptomatic CD represents only the tip of the iceberg.

It is estimated that, theoretically, for each case with malabsorption symptoms there are 7 cases clinically silent.

In the adulthood, the disease diagnosis is usually made ten years after the first symptoms onset. ${ }^{5}$ The current epidemiological studies, made on the serological test and the biopsy specimen, suggest a disease prevalence between 1:70 and 1:300 in most of the countries. The disease is common in female sex, with male-female ratio of 1:2.5. Population studies reported such a variability in $\mathrm{CD}$ prevalence between different peoples, which not always found a relationship with the predisposing genes DQ2/DQ8 distribution neither with the different gluten consumption.

Epidemiological studies describe a prevalence increase of the disease with age, too. There are groups of people, as type-1 diabetes patients, the ones affected by autoimmune thyroid disease, Turner and Down syndromes, first degree CD or type- 1 diabetes patients' relatives who are at higher risk of the disease, for the presence of predisposing factors. The letters can achieve $5-10 \%$ of incidence rate.

Some studies affirm that the CD epidemiology is changing not only for the increasing sensitivity of diagnostic tests, but also for a real rising of incidence. ${ }^{6}$

\section{Pathogenesis}

Celiac disease is a complex multigenic disorder that involves both HLA and non-HLA genes, environmental factors, innate and adaptive immunity ${ }^{7}$ and a relevant component of T-cell mediated autoimmunity. ${ }^{8}$

Susceptibility for CD is strongly associated with II class HLA genes, such as $H L A-D Q 2$ and $H L A-D Q 8$, cell membrane glycoproteins codified by HLA-DQA1 and $H L A-D Q B 1$, located in the chromosome region $6 \mathrm{p} 21.3$.

Although over $90 \%$ of $\mathrm{CD}$ patients present both $H L A-D Q 2$ and $-D Q 8,{ }^{9,10}$ not all people who carry both those alleles suffer from $\mathrm{CD}$; furthermore $30-40 \%$ of the general population carry the same alleles of celiac disease.

The fact that HLA-identical twins do not present a $100 \%$ concordance rate, suggests that non-HLA genes are involved, ${ }^{11}$ besides environmental factors. The majority of those non-HLA genes, to which is attributed only 3 to $4 \%$ of genetic susceptibility for CD, code for immunological relevant proteins that play a role in antigen presenting cells and T-linphocytes. ${ }^{11}$ The immunologic abnormality in patients with $\mathrm{CD}$ determines the development of antibodies against gliadin (AGA), ${ }^{12} \mathrm{en}-$ domysium (EmA) and anti-transglutaminase 2 (tTG2), which is an endogenous gliadin-binding enzyme. There are two reasons why gliadin is capable of starting immune response in $\mathrm{CD}$ : firstly, its high content in proline which renders the molecule resistant to degradation by salivary and gastric protease allowing it to reach the intestinal lumen as a long fragment of 10-15 amino acids; secondly, this long fragment represents the substrate for TG2, which converts glutamine remnants in glutamate (by deamidation). This process confers electronegativity to the molecule thus increasing its tendency to bind to $H L A-D Q 2$ and $-D Q 8$.

TG2 regulated post-translational modifications of gluten, apparently play a crucial role in $\mathrm{CD} 4+$ specific response by producing a neo-antigen ${ }^{11}$ which could result from the bond between gliadin and TG2, thus creating anti-TG2 antibodies. CD4+ T cells recognize deamidated peptides presented by $H L A-D Q 2$ and $D Q 8$ and produce interferon gamma (IFN $\gamma$ ) that causes inflammation and atrophy of the villi. Moreover, gluten itself is capable of activating CD8+ Tcells in the lamina propria [intra-epithelial lymphocytes (IEL)]. ${ }^{11}$

Activated IELs are capable of inducing apoptosis and increasing expression and activation of the epidermal growth factor receptor. Some studies showed that gliadin peptides can activate innate immunity, for instance trough Toll-like receptor 4 and the natural killer (NK) cells, therefore inducing production of IFN $\alpha$ and interleukin-15 (IL-15). ${ }^{11}$ IL-15 activates NK cells' receptors in intraepithelial lymphocytes; intraepithelial lymphocytes destroy the epithelium through cytolysis and IFN $\gamma$ release. This is why hepatitis $\mathrm{C}$ treatment with IFN $\alpha$ can be associated with the induction of a gluten-directed inflammatory response with generation of anti-tTG antibodies..$^{13}$ This is also the reason why there is a strong association between $\mathrm{CD}$ and Down syndrome since the gene that encodes for IFN $\alpha$ receptor is located on chromosome $21 .{ }^{14}$

Among the environmental factors associated with 
$\mathrm{CD}$, the most relevant is surely gluten consumption. ${ }^{7}$ Some authors have emphasized the possible role of viral infections (recurrent Rotavirus infections can increase the incidence of $\mathrm{CD},{ }^{15,16}$ particularly in patients with unfavorable genetic polymorphisms linked to response to viral infections). ${ }^{7}$ Finally, in the last years, the study of intestinal microbiota has raised interest, even though at present results are still controversial. In fact, while some authors did not find any statistically significant differences between the microbiota of celiac patients and healthy controls, ${ }^{17}$ some others have found that in the microbiota of celiac patients there is a reduction of beneficial bacterial species and an increase of potentially pathogenic ones compared to healthy controls; such dysbiosis apparently would persist even after the introduction of a gluten-free diet. ${ }^{18}$

\section{Clinical presentation}

$\mathrm{CD}$ can be difficult to recognize given its wide variability of symptoms and signs. ${ }^{19} \mathrm{CD}$ is one of the most common causes of intestinal malabsorption: ${ }^{2}$ the damage to intestinal villi of the small bowel leads to a reduced absorption of micronutrients such as liposoluble vitamins, iron and, potentially, folic acid and B12. Consequently, diarrhea, weight loss, failure to thrive in pediatric age, abdominal pain and bloating represent the most common symptoms of $\mathrm{CD}$. In some other cases the symptomatology can be less evident, involving either or both the intestine and other organs; for instance, some adults can present only with fatigue and anemia, while at times symptoms of CD can be totally absent: from classical malabsorption-driven picture to light or absent symptoms associated with moderate damage of intestinal mucosa.

According to the recent Oslo definitions, ${ }^{20}$ Classical $C D$ is defined as $C D$ presenting with signs and symptoms of malabsorption. Diarrhea, steatorrhea, weight loss or growth failure is required.

Asymptomatic $C D$ (previous silent $C D$, but the recent Oslo definitions discourage the use of this term) is not accompanied by symptoms even in response to direct questioning at initial diagnosis. Individuals with asymptomatic $\mathrm{CD}$ do not manifest any symptoms commonly associated with $\mathrm{CD}$ and have no symptoms that respond to gluten withdrawal, even in response to direct questioning. These patients are often diagnosed through testing of populations enrolled in screening programs or in case-finding strategies for detecting $\mathrm{CD}$ in patients with disorders that are associated with a high risk for $\mathrm{CD} .{ }^{20}$ Sometimes minor symptoms (e.g., fatigue) are only recognized after the introduction of a gluten-free diet (GFD); such patients do not suffer from true asymptomatic $\mathrm{CD}$ and should be reclassified as having subclinical CD.

In the non-classical CD (CD presenting without signs and symptoms of malabsorption) the patient does not suffer from malabsorption (e.g., a patient with constipation and abdominal pain but no malabsorption). ${ }^{20}$

Table 1 lists a series of conditions that are observed more frequently in $\mathrm{CD}$ patients compared to healthy controls (with a prevalence at least two times higher) and/or conditions that could find benefit from GFD. ${ }^{2}$

Table 1. Conditions associated with celiac disease and/or conditions that could find benefit from a gluten-free diet.

\begin{tabular}{ll}
\hline Common associations & Less common associations \\
\hline Symptomatic malabsorption & Pulmonary hemosiderosis \\
\hline Diarrhea with weight loss & Inexplicable male or female infertility \\
\hline Chronic diarrhea with or without abdominal pain & Dyspepsia \\
\hline Hypoferritinemia with or without anemia & Amenorrhea \\
\hline Altered mineral metabolism with early onset of osteoporosis & Chronic fatigue \\
\hline Bloating & Malabsorption of thyroid replacement therapy \\
\hline Unexplained weight loss & Epilepsy or ataxia \\
\hline Hypertransaminasemia & Constipation \\
\hline Accidental endoscopic or histologic finding of villi atrophy & Recurrent abdominal pain \\
\hline Dermatitis herpetiformis & \\
\hline Peripheric neuropathy & \\
\hline Mouth ulcers & \\
\hline Failure to thrive & \\
\hline Thyreopathies & \\
\hline Irritable bowel syndrome & \\
\hline Dyschromia of teeth enamel & \\
\hline Down and/or Turner syndrome & \\
\hline Adapted from Rubio-Tapia et al., $2013 .^{2}$ & \\
\hline
\end{tabular}




\section{Diagnostic tests}

Diagnosis of celiac disease hinges on a diagnostic intestinal biopsy and the concomitant presence of a positive celiac disease-specific sierology, ${ }^{4}$ with a greater sensibility of the two tests in those who are consuming a gluten-containing diet. Indeed, in glutenfree diet patients, antibodies are negative, biopsies were not oriented correctly (this could lead to falsenegative or false-positive villous atrophy) or show solely intraepithelial lymphocytosis (lymphocytic duodenosis) without architectural changes..$^{21}$ Therefore patients need to be maintained on a gluten containing diet until the end of the diagnostic tests to avoid false negative tests.

Antibody detection: $\operatorname{IgA}$ and $\operatorname{IgG}$ antibodies can be detected in blood samples of patients by various immunoassays, but generally, only the IgA antibodies could be considered highly specific and sensitive for the celiac disease. IgG-based tests are useful for detecting $\mathrm{CD}$ in selected IgA-deficient patients, a frequently associated disease. ${ }^{22,23}$

Conventional AGA are nowadays considered obsolete for diagnostic purposes because of their disappointing low sensitivity and specificity. ${ }^{24,25}$

The recent introduction of methods for the determination of anti-transglutaminase (anti-tTG) has significantly reduced the clinical use of antibodies AGA, although their use is important in children aged between 0 and 5 years because of the evidence of autoantibody seroconversion reported recently for celiac disease (between 5 and 7 years). ${ }^{26}$

Nowadays the two most valid tests for the serological diagnosis of celiac disease are the EmA and antitTG. The EmA $\operatorname{IgA}$, when measured with indirect immunofluorescence method, can identify $94 \%$ of celiac disease with a specificity almost $100 \%$, but fluctuating values are possible in first-degree relatives and in patients affected by type- 1 diabetes mellitus.

Testing for EmA antibodies is considered the reference standard for $\mathrm{CD}$-specific antibody detection in expert laboratories, whereas sufficient sensitivity and specificity was not achieved in laboratories without a sufficient experience in immunofluorescence assay. Beyond increased specificity of EmA antibodies, testing for anti-tTG should be the first choice for screening of $\mathrm{CD}$ because of its highest sensitivity, reproducibility and availability.

In most laboratories the EmA are currently used as a confirmatory test for positive cases for anti-tTG. ${ }^{22,23,27}$

A more recent marker for $\mathrm{CD}$ are the antibodies against synthetic deamidated gliadin peptides (DGPs) with a sensitivity of $84 \%$ for both IgA and IgG and a specificity of $99 \%$. This test performs favorably and much better than previous antibodies against native gliadin and, although its performance is inferior com- pared with anti-tTG or EmA, anti DGPs IgG specificity is comparable to the specificity of EmA IgA and higher than anti-tTG IgA. ${ }^{27}$

A new antibodies strategy based on the combined determination of anti-tTG IgA and IgG DGPs could be adopted. The combination of IgG-DGPs and IgATG2 is particularly useful as an addition to detection of patients with $\mathrm{CD}$ who are IgA deficient and to confirm the specificity of the anti-tTG ( $9 \%$ of false positive). Moreover, anti-DGPs are excellent marker for diagnosing $\mathrm{CD}$ under 2 years old. Therefore, the combination strategy using anti-tTG IgA and anti-DGPs would reduce the tests necessary for the diagnosis of $\mathrm{CD}$, reducing the use of Ema IgA, anti-tTG IgG and AGA IgA (Figure 1). ${ }^{27}$

CD-specific serological tests, which have been in use for $>20$ years now, are important for 2 purposes: to select patients in whom biopsies are appropriate and to confirm the diagnosis in cases in which an enteropathy has been detected. ${ }^{4}$ However, antibody testing is negative in $6-22 \%$ of cases of celiac disease ${ }^{28-31}$ (Table 2), ${ }^{2}$ hence if a celiac disease is strongly suspected even if serological tests are negative, it is important to proceed with a duodenal biopsy. ${ }^{27}$

\section{Duodenal biopsy}

The morphological analysis of the duodenum cell samples extracted during the biopsy significantly helps diagnose or discount a possible celiac disease, assess the damages and identify any further complication arising from the disease. Beyond the confirmation of the diagnosis, the histologic test plays a crucial role for the differential diagnosis through endoscopic patterns similar to those used for the celiac disease.

From the histological point of view, the celiac disease is accompanied by a progressive flattening of the mucosa, which culminates with the villous atrophy, associated with hypertrophy of the crypts, infiltration of inflammatory cells (plasma cells, lymphocytes, eosinophils, and mast cells) at the lamina propria, as well as with an increased amount of immunoglobulins (IgA, IgG and $\operatorname{IgM}){ }^{32}$ Moreover, under normal conditions, the tight junctions between the enterocytes of the intestinal mucosa prevent the macromolecules from reaching the lamina propria, acting as an impermeable barrier, while, in case of celiac disease, a cytoskeletal alteration of the enterocytes allows for the migration of lymphocytes towards the cells featuring the antigen, which are thus activated.$^{33}$ However, the histological damage detected is typical but not pathognomonic, since it can be linked to many other diseases, including tropical sprue, Whipple's disease, intestinal lymphoma, Crohn's disease, etc.

In case of celiac disease, this phenomenon generally affects the mucosa at the proximal section of the 
small intestine, then proceeding - with a lower severity - towards its distal portion, although it may sometimes involve also the more distal portions ${ }^{34,35}$ or even the gastric and rectal mucosa.

The severity and extent of the histological damage are usually connected to the degree of the clinical symptoms. ${ }^{36}$ Furthermore, some patients may have normal mucosal conditions, even in case of antibody positivity. ${ }^{37-39}$

The Marsh histological classification, which is universally recognized and validated, ${ }^{35,40}$ helps assess the orientation of the villi, the presence of normal villi,

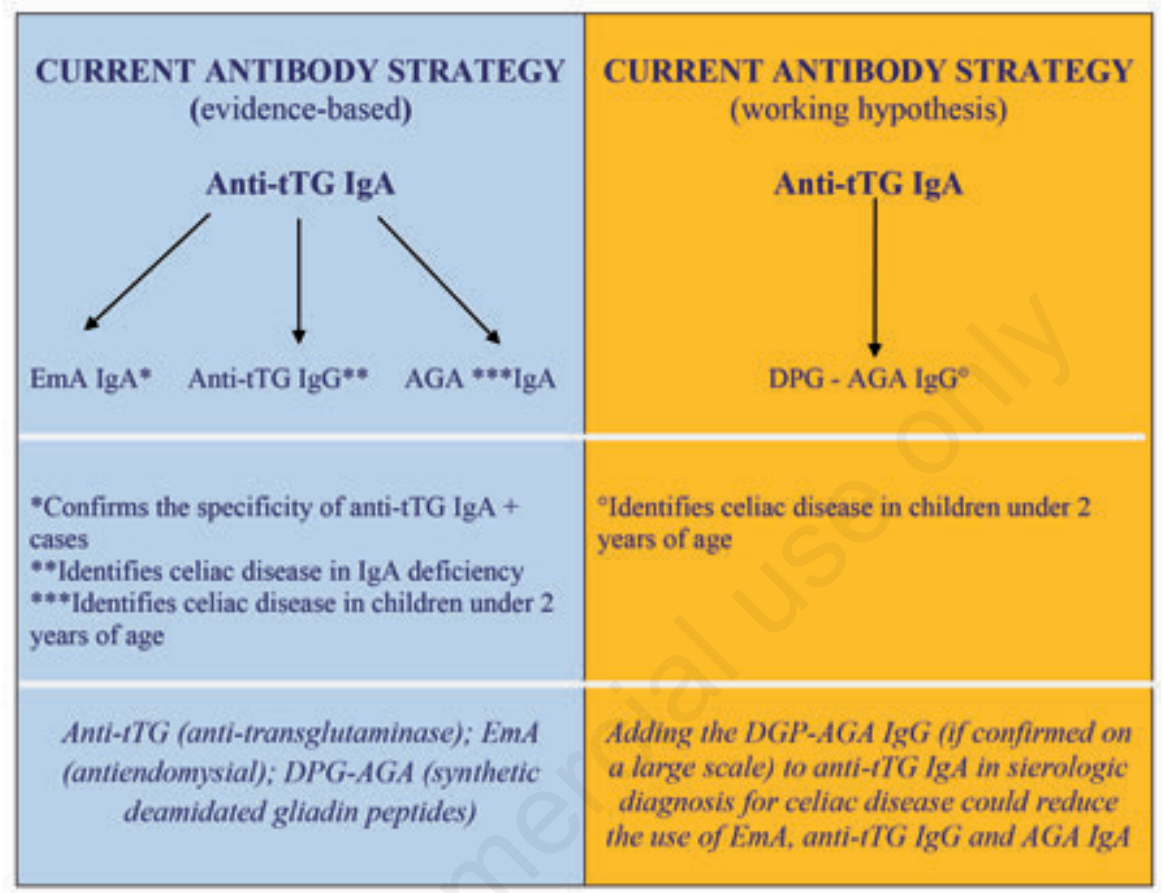

Figure 1. Comparison between the current antibody strategy and the working hypothesis for the future for celiac disease diagnosis. Modified from Volta, 2009.27

Table 2. Serological diagnosis of celiac disease.

\section{Recommendations}

1. Immunoglobulin A (IgA) anti-tissue transglutaminase (tTG) antibody is the preferred single test for detection of celiac disease (CD) in individuals over the age of 2 years (Strong recommendation, high level of evidence)

2. When there exists a high probability of CD wherein the possibility of IgA deficiency is considered, total IgA should be measured. An alternative approach is to include both IgA and IgG-based testing, such as IgG-deamidated gliadin peptides (DGPs), in these high-probability patients (Strong recommendation, moderate level of evidence)

3. In patients in whom low IgA or selective IgA deficiency is identified, IgG-based testing (IgG DGPs and IgG tTG) should be performed (Strong recommendation, moderate level of evidence)

4. If the suspicion of CD is high, intestinal biopsy should be pursued even if serologies are negative (Strong recommendation, moderate level of evidence)

5. All diagnostic serologic testing should be done with patients on a gluten-containing diet (Strong recommendation, high level of evidence)

6. Antibodies directed against native gliadin are not recommended for the primary detection of CD (Strong recommendation, high level of evidence)

7. Combining several tests for CD in lieu of TTG IgA alone may marginally increase the sensitivity for CD but reduces specificity and therefore are not recommended in low-risk populations (Conditional recommendation, moderate level of evidence)

8. When screening children younger than 2 years of age for CD, the IgA TTG test should be combined with DGP (IgA and IgG) (Strong recommendation, moderate level of evidence)

Adapted from Rubio-Tapia et al., 2013. ${ }^{2}$ 
their atrophy degree, the depth of the crypts, the villus/crypt ratio and the amount of IELs.

Upon the completion of the relating study, a change has been introduced by Oberhuber and his team, ${ }^{41,42}$ which requires the breakdown of Marsh 3 lesion into three groups.

According to this classification, these patterns can be divided into infiltrative, hyperplastic and atrophic ones (Table 3$)^{2}{ }^{2}$

\section{Genetic analysis}

In some selected cases, for example, patients with diverging serologic and histologic values, individuals who are already sticking to a strict gluten-free diet and have never been subjected to a test, or relevant histological results (Marsh I-II) in patients with negative immunological test, the performance of some ancillary tests is highly recommended, including the HLA$D Q 2 / D Q 8$ serotype group. ${ }^{2}$ Although the absence of both DQ2 and DQ8 implies the unlikelihood of developing this disease, their presence does not automatically indicate its onset. Therefore, in the event of a high negative predictive value, the HLA analysis can play a crucial role for the diagnosis of the celiac disease. ${ }^{43,44} \mathrm{~A}$ diagnostic algorithm referring to the $\mathrm{CD}$ is shown in Figure 2. ${ }^{2}$

\section{Role of the endoscopic video capsule for the diagnosis of the celiac disease}

The endoscopic capsule grants a non-invasive visualization of the small intestine mucosa.$^{45}$ According to the American College of Gastroenterology (ACG) 2013 clinical guidelines, ${ }^{2}$ the use of this video capsule is limited to the assessment of the small intestine mucosa in patients affected by complex forms of celiac disease (strong recommendation, remarkable evidence level).

\section{Potential celiac disease}

The term potential CD (PCD) was assigned to individuals with proper DQ2 or DQ8, production of anti-tTG antibodies and normal small intestinal mucosa, classified as Marsh 0 (no damage) or Marsh 1 stage (unspecific intra epithelial infiltration only). ${ }^{37}$

Therefore, PCD patients have the celiac type HLA, positive anti-transglutaminase antibodies but no damage at small intestinal mucosa. PCD patients suggest that the development of adaptive anti-gluten immunity is not sufficient to develop villous atrophy. ${ }^{20}$

A difficulty in the definition of this group is variability in the adequacy of the biopsies that were taken to exclude the diagnosis of active CD, especially with the current knowledge that at least four biopsies need to be taken ${ }^{46}$ and the bulb may be the only location of villous atrophy (VA). ${ }^{20}$

The major clinical problem is the management of asymptomatic patients and how to predict the development of VA. ${ }^{38}$ Indeed a significant number of PCD patients showed fluctuation or negativity of antibody production, and many of these, with persistently positive anti-TG2, have not developed mucosal damage after several years of follow-up. ${ }^{38}$

The same guidelines ESPGHAN (3) help to define celiac disease as a systemic immune-mediated disease, which include, but not necessarily, enteropathy, thus providing cases where no histological damage is present. To confirm this consideration, the authors have reported cases of subjects with PCD whose symptoms recede the gluten-free diet. However, the majority of PCD patients do not have symptoms and, while levels of anti-TG2 are constantly high, they do not develop mucosal damage after nine years of follow-up $8 .{ }^{38} \mathrm{Cau}-$ tion is required before prescribing a gluten-free diet for life of asymptomatic individuals with a potential CD. ${ }^{38}$

Indeed, it is still questionable whether patients with PCD should be treated by GFD or whether they should

Table 3. Histological classification of the celiac disorder.

\begin{tabular}{lcccc}
\hline Marsh modified (Oberhuber) & \multicolumn{3}{c}{ Histological criteria } & Corazza \\
\cline { 2 - 5 } & $\begin{array}{c}\text { Intraepithelial } \\
\text { lymphocytes elevation* }\end{array}$ & Crypt hyperplasia & Villous atrophy & None \\
\hline Type 0 & No & No & No & Grade A \\
\hline Type 1 & Yes & No & No & No \\
\hline Type 2 & Yes & Yes & Grade B1 \\
\hline Type 3a & Yes & Yes & Yes (partial) & \\
\hline Type 3b & Yes & Yes & Yes (subtotal) & Grade B2 \\
\hline Type 3c & Yes & Yes & Yes (total) & \\
\hline
\end{tabular}

*>40 intraepithelial lymphocytes per 100 enterocytes according to the revised Marsh classification (Oberhuber); $>25$ intraepithelial lymphocytes per 100 enterocytes pursuant to the Corazza classification. Adapted from Rubio-Tapia et al., 2013. ${ }^{2}$ 
be kept on a gluten-containing diet with a very close serological, clinical and histological follow-up. It is necessary to identify such subgroup of patients who will develop or less atrophy of the villi, ${ }^{38}$ but the ESPGHAN guidelines, ${ }^{3}$ although providing the definition PCD, do not indicate the clinical and therapeutic management.

In the absence of official directives, the tendency, supported by clinical studies conducted in recent years, ${ }^{38}$ is to propose a gluten free diet only to potential celiac symptomatic. If the symptoms do not improve and therefore cannot be found a reliable link with gluten exposure, a free diet is recommended, monitoring the patient at regular intervals.

\section{Non-celiac gluten sensitivity}

Non-celiac gluten sensitivity (NCGS) is a syndrome characterized by intestinal (most commonly including bloating, abdominal pain and diarrhea) and extra-intestinal symptoms (among which fatigue, headache, anxiety and cognitive difficulties feature prominently) related to the ingestion of gluten-containing food, in subjects that are not affected by either celiac disease or wheat allergy. ${ }^{47-49}$

The prevalence of NCGS is not clearly defined yet. Indirect evidence suggests that NCGS is more common than $\mathrm{CD},{ }^{47}$ the latter affecting around $1 \%$ of the general population. ${ }^{47}$ Treatment of NCGS is based on the celiactype GFD although it is unknown if long-term, strict avoidance of all gluten-related products is necessary. Since NCGS may be transient, gluten tolerance needs to be re-assessed in patients with NCGS. ${ }^{47}$

Although the symptoms of NCGS are similar to those of celiac disease, however, unlike the celiac disease, the NCGS does not have a genetic predisposition, the role played by the immune system is not clear, it is not associated with malabsorption and vitamin or nutrient deficiency and is not linked to a higher risk of autoimmune diseases or intestinal neoplasias. ${ }^{17}$

As it is not possible to differentiate celiac disease by a NCGS by symptoms alone or with the disappear-

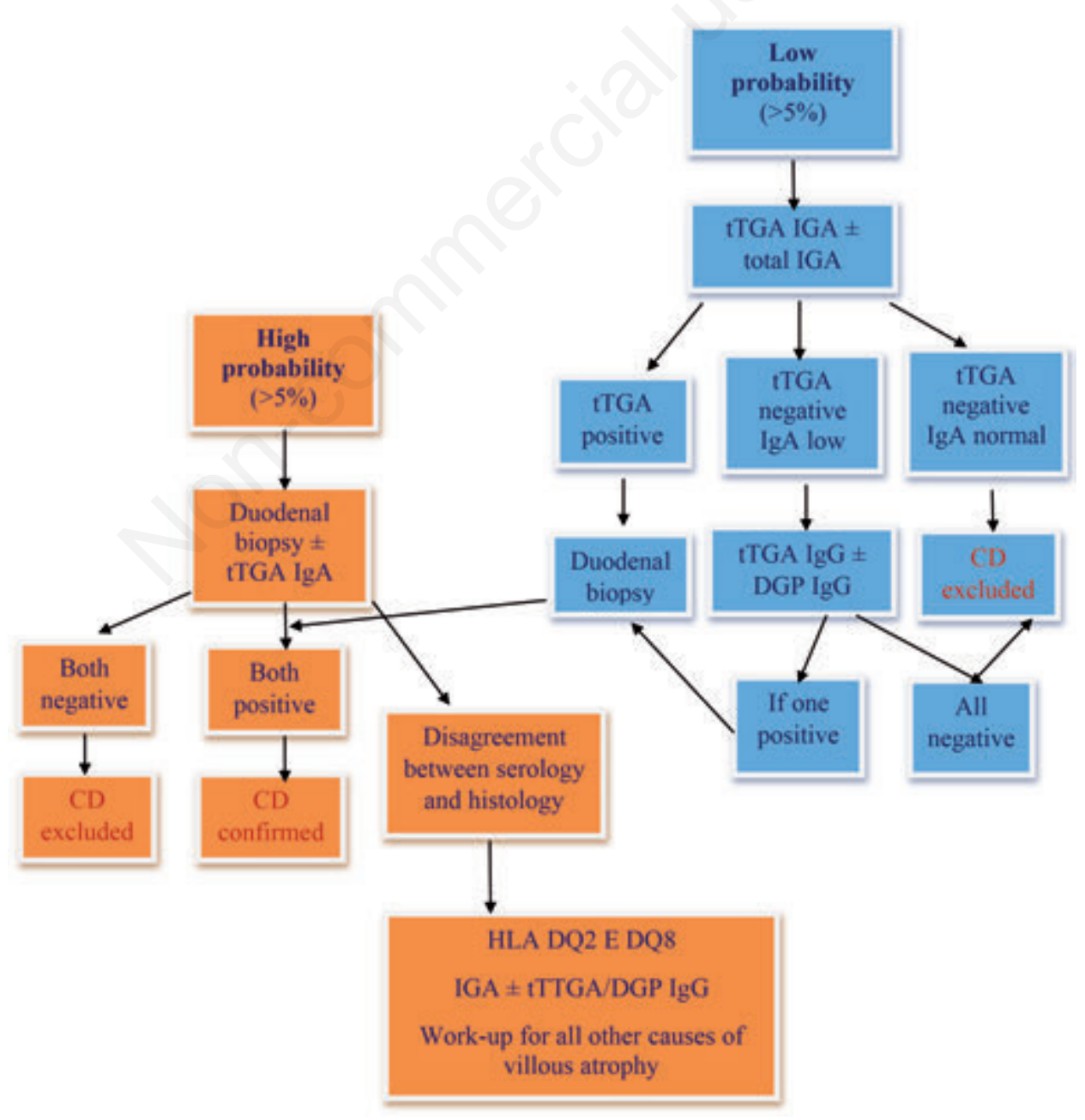

Figure 2. A diagnostic algorithm referring to the celiac disease (CD). Adapted from Rubio-Tapia et al., $2013 .^{2}$ 
ance of these with a gluten-free diet ${ }^{48-50}$ and there are currently no specific diagnostic tests, therefore remains a diagnosis of exclusion after the diagnostic tests for celiac disease or wheat allergy were negative.

Recently, the Salerno Experts' Criteria ${ }^{47}$ want to help the clinician to reach a firm diagnosis and positive NCGS. The clinical evaluation is performed using an instrument of self-administration incorporating a modified version of gastrointestinal symptom rating scale. The patient identifies one to three main symptoms that are quantitatively evaluated using a numerical rating scale with a score from 1 to 10 . The double-blind placebo-controlled gluten challenge $(8$ $\mathrm{g} /$ day) includes a challenge to a week followed by a one-week washout of strict GFD and by the crossover to the second one-week challenge. The vehicle should contain cooked, homogeneously distributed gluten. At least a variation of $30 \%$ of one to three main symptoms between the gluten and the placebo challenge should be detected to discriminate a positive from a negative result. ${ }^{47}$

\section{Complications and follow-up}

Celiac disease had generally a benignant course and this datum is confirmed to five-years survival rate that ranged from $80 \%$ to $96 \% .51,52$

The CD is the only treatment recognized as effective and, at present, there are no side effects and no drugs that can significantly prevent or fix the damage to the intestinal mucosa caused by exposure to gluten. Moreover, there is evidence that CD improves nutritional parameters in adults and symptomatic children, including an increase in body weight, body mass index and bone mineralization. ${ }^{53}$ Although the term glutenfree implies a complete elimination of all sources of gluten, in reality this is not possible because of possible contamination of food with traces of gluten. Therefore, the term refers, in a practical way, to a diet that contains gluten in a lower amount to the maximum level tolerated that a recent review suggests as equal to $10 \mathrm{mg}$ per day. ${ }^{54,55}$

The lack of adherence to GFD can lead to a gradual increase in the incidence of complications with consequences on the patient's health status and increased risk of mortality. In particular, patients with $\mathrm{CD}$ who do not adhere to the gluten-free diet have an increased risk of neoplastic complications, such as small bowel adenocarcinoma, esophageal cancer and $\mathrm{B}$ and T cells non-Hodgkin's lymphoma. ${ }^{56}$

The untreated CD is associated with an increased prevalence of conditions by low bone mineral density (osteopenia and osteoporosis), largely explained by the low values of vitamin D deficiency from intestinal absorption; in general, it is the main cause of an increased risk of bone fractures in these patients. ${ }^{57,58}$
Then, women with CD have, an increased risk of infertility, miscarriages, pre-term and give birth to infants with low birth weight parts. The treatment of women with $\mathrm{CD}$ with gluten-free diet reduces these risks at rates similar to those of the general population. ${ }^{59-62}$

\section{Refractory celiac disease}

The refractory CD (RCD) is characterized by persistent or recurrent malabsorption symptoms and signs with villous atrophy despite a strict gluten free diet for more than 12 months. ${ }^{20}$ Although RCD definitions differ slightly, , $2,63-69$ most expert-opinion-based definitions include persistence or recurrence of malabsorption symptoms and signs (e.g., diarrhea, abdominal pain, involuntary loss of weight, low hemoglobin, and hypoalbuminemia) associated with persistent or recurrent VA despite a strict GFD for more than 12 months (or severe persistent symptoms independently of the duration of GFD) in the absence of other causes of VA or malignant complications ${ }^{70,71}$ and after the confirmation of the initial diagnosis of $\mathrm{CD} .{ }^{20}$

Generally, most patients have negative EMA and TTG antibodies at the time of RCD diagnosis, but the presence of persisting elevated titers of circulating EMA and/or TTG antibodies does not necessarily rule out RCD, though this should lead to questions about dietary adherence. In all cases, a careful dietary interview should be performed to exclude gluten exposure before diagnosing RCD. ${ }^{66}$ Not all dietary non-responsive CDs are refractory CDs. ${ }^{67}$

There are several causes that may favor the onset of a RCD of which the accidental ingestion of gluten is the most frequent cause, followed, clashing with other food allergies, including lactose and fructose intolerance, bacterial overgrowth, the presence of a concomitant microscopic colitis, a concomitant pancreatic insufficiency, irritable bowel disease, or a true lack of response to a gluten free diet. ${ }^{68,62,72-75}$ For this reason, a thorough evaluation is required in all those patients who do not show a clinical resolution of the disease. ${ }^{63-66}$ The first step of the evaluation of these patients is to obtain the confirmation of the initial diagnosis of celiac disease, subjecting them to serological, endoscopic and histological revaluation. If the diagnosis is incorrect, it is mandatory to consider other diagnoses without waiting for any subsequent response to the gluten-free diet. ${ }^{64}$ In cases where the disease is confirmed, the accidental ingestion of gluten is the most frequent cause of RCD. ${ }^{63,64}$ In these cases the serological surveys may be helpful, if positive, to diagnose with certainty accidental exposure to gluten as the cause of RCD. ${ }^{60}$ Nevertheless, since a normal serology does not allow to exclude forms of RCD related to small and discontinuous dietary contamination 
with gluten, in these cases, an accurate assessment of eating habits is required by a dietitian specialized in the management of the $\mathrm{CD}$. The evaluation must also include the search for coexistence of food intolerances, such as fructose and lactose. When any dietary cause of RCD has been excluded, it is necessary to supplement its investigation by endoscopic and histological evaluation of the disease. The presence of enteropathy with intestinal villous atrophy can be compatible with refractory celiac disease, intestinal bacterial overgrowth or other causes of villous atrophy. ${ }^{63,65,76-78}$ Abnormal histological data should also lead us to discover other possible causes of RCD as microscopic colitis. ${ }^{63-65,74}$

It is possible to classify the RCD in two distinct forms: i) the type $1 \mathrm{RCD}$, in which the infiltration of lymphocytes in the mucosa of the small intestine is similar to that of subjects not treated with $\mathrm{CD}$ and a normal IEL phenotype is found; ${ }^{74,78,79}$ ii) the type 2 $\mathrm{RCD}$, in which there is a clonal expansion of an aberrant IEL population: the CD3-positive lymphocytes intraepithelial exhibit an abnormal or atypical immunophenotype with the loss of normal expression of differentiation markers present on the cell surface as those of the CD 8. ${ }^{78,79}$ Furthermore, the analysis of Tcell receptors may detect an oligoclonal expansion present in the entire surface of the intestinal mucosa. ${ }^{67,74,78,79}$ The presence of these abnormalities in lymphocyte T cells in type $2 \mathrm{RCD}$ is associated with a significantly worse prognosis than that estimated for patients with forms of RCD type $1 .^{74,75}$

The management of type 1 RCD includes the exclusion of an accidental ingestion of gluten, covering an evaluation and consequent possible treatment of any nutritional deficiency. ${ }^{64,74,80}$ It is often necessary, the symptomatic treatment of diarrhea in order to reduce its impact on patients' quality of life and in extreme cases, the traditional medical treatment consists in the use of systemic steroids such as prednisone.

In the type 2 RCD the GFD is the only measure that can prevent the lymphomatous transformation. As in the RCD form of type 1 any nutritional deficiencies should be corrected; unlike the RCD form of type 1 there is no indication to the use of immunosuppressive drugs. ${ }^{81}$ Furthermore, the azathioprine may accelerate the risk of a transformation of RCD in lymphomatous forms. ${ }^{51,82,83}$ Although steroids can exert beneficial clinical effects, they have no influence in curbing the possible transformation into enteropathy associated with T-cell lymphoma, and especially, the prompt therapeutic response to these medications cannot exclude an underlying lymphomatous condition. ${ }^{81}$ Given this possible development in patients with type 2 RCD enteropathy associated with T-cell lymphoma, the goal of treatment is to destroy the population of aberrant cell which in the future could turn into lymphoma. Cladribine is a syn- thetic purine nucleoside with homologous, whose cytostatic effect inhibits the proliferation and division of lymphoid cells. ${ }^{84}$ It is successfully used in malignant forms with low degree of proliferation, such as hairy cell leukemia, and may also be effective in the treatment of type 2 form of RCD. ${ }^{84}$

\section{The patient with celiac disease: the Italian legislative aspects}

According to the Decree of the Italian Ministry of Health, May 18, 2001, No. 279 celiac disease has been inserted in the list of rare diseases with the RI0060 code, together with dermatitis herpetiformis. ${ }^{85}$ This occurred despite the celiac disease may not be strictly defined as a rare disease. In fact, at that time, the prevalence of celiac disease was estimated to 1:250 inhabitants, while the definition of rare disease corresponds, in the European definition, to a prevalence of not more than 1:2000 inhabitants.

The ministerial legislation established an exemption from a co-payment for clinical tests, genetic tests included, necessary required to diagnose the disease. This right was extended to the first-degree relatives (parents, children, siblings) of the patient with celiac disease. In the same decree the Central Government delegates to the regions the task of defining the centers with necessary expertise in the diagnose and certification of rare diseases. Moreover, the national network of rare diseases has been instituted and has been assigned the task of collecting the case studies, patients' data (maintaining anonymity), and clinical and laboratory data. Furthermore, a Ministerial Decree, enacted a month later, on $8^{\text {th }}$ June 2001, permitted the celiac subjects to charge the fees for special dietary food on the National Health System. The gluten-free food is significantly more expensive than conventional one. In many other countries patients receive economic assistance to offset against this cost excess. However, this kind of assistance considerably varies in each country and also among different regions of the same nation, from a fully funded, to tax-deductible, or, in the form of a monthly support that in Europe varies from 20 to $200 € .{ }^{86}$ In Italy the Government has chosen the last option, differentiating the amount of contribution based on gender and age of the patient, i.e. depending on the need of calories. ${ }^{87} \mathrm{Ac}-$ cording to the Government's document dated December $31,2012,{ }^{88}$ the Ministry of Health has updated the list of the accredited facilities that are able to certify and the list of the second-level referral centers in Italy. The advent of the new essential levels of care (better known in Italian as $L E A$ ) has moved the celiac disease from rare condition to chronic debilitating disease but the fact that it has been excluded from the list of these diseases, raises some concerns about complications, 
in particular the refractory sprue that instead has a compatible prevalence with the definition. However, in the proposal of the LEA, celiac disease unlike the ministerial list of chronic disabling diseases, has not a coded list of diagnostic tests on charge of the National Health System. They are at clinician's discretion who may consider them appropriate or not for the disease and its complications. With the publication of the document G.U. No. 191 of $19^{\text {th }}$ August 2015, ${ }^{89}$ the Ministry of Health has delegated a consensus to a group of experts responsible for the definition of the diagnosis guidelines and the national follow-up on celiac disease. In particular pediatric diagnostics, where jejunal piopsy is not always necessary, has been differentiated from that of the adults. In pediatric diagnostics intestinal biopsy can be avoided only in symptomatic patients with high titers of anti-tTG antibodies, confirmed by EmA and HLA positivity.

Symptoms and diseases most frequently associated with celiac disease have been listed, with the purpose to promote early diagnosis. The commission also defines the frequency of follow-up, or a first check 6-12 months after diagnosis, subsequent check tests every 1-2 years, and not necessarily every year. Second-line blood tests are necessarily indicated for the diagnosis, among them, iron metabolism (serum iron, ferritin) and folates that must be performed after the first check in case they result altered or if the blood count is suggestive of their deficiency. Only in this case, the test will be repeated annually until normalization. The thyroid stimulating hormone dosage and peroxidase antibodies are prescribed at diagnosis and, if normal, repeated every 3 years. The protocol also indicates the opportunity to perform a bone densitometry in adults after 18 months of gluten-free diet, reserving the subsequent tests at the discretion of the physician. However, the curators of the protocol give the opportunity to specialists to define any necessary tests to monitor the disease, complications and related illnesses, and emphasize what surely results as inappropriate: i) running too early the tests of anti-transglutaminase title after starting the diet, running too frequently tests for the suspect of celiac disease due to acute symptoms, anaphylaxis, also gastrointestinal, that appears in close temporal relation with the intake of gluten; ii) starting a gluten-free diet as a criterion, without having a diagnosis of celiac disease; iii) perform HLA typing as the unique diagnostic investigation.

\section{The management of patients with celiac disease: methodology}

In order to provide evidence-based recommendations for the management of patients with celiac disease, we first verified the existence of guidelines on the topic.
A systematic review of syncope-focused guidelines was performed accessing Medline via PubMed and the following guidelines-focused databases:

- Scottish Intercollegiate Guidelines Network (SIGN);

- Institute for Clinical Systematic Improvement (ICSI);

- National Institute for Health and Clinical Excellence (NICE) (NHS evidence);

- National Guideline Clearinghouse (NGC);

- Agency for Healthcare Research and Quality (AHRQ);

- Canadian Medical Association, CMA infobase;

- New Zealand Guidelines Group;

- Sistema Nazionale Linee Guida (SNLG - Italian National Guidelines System);

- Clinical Practice Guidelines Portal;

- eGuidelines.

The research was carried out by six authors independently, using the term celiac disease as key-word when the site included the search function, and in other cases we listed the last guidelines manually stored in the database, from 2007 until 2014. The Medline literature strategy is available upon request. The inclusion process involved a two-step phase and a quality assessment. The results obtained separately were compared and discussed together subsequently.

Then, the obtained guidelines were evaluated using the Appraisal of Guidelines, Research and Evaluation II (AGREE II) instrument ${ }^{90}$ by 5 authors independently, in order to identify the guidelines that were qualitatively better. AGREE II assesses compliance with 23 requirements, meeting 6 domains as the explanation of the purpose, the clarity, the involvement of all stakeholders, the rigor of development, applicability and editorial independence of the same. Each author assessed the compliance of individual requirements with a score from 1 (disagree completely) to 7 (complete agreement). The scores assigned by each author were added within individual domains and reported with the highest and the lowest possible score within the domain based on the included number of requirements and evaluators.

In order to update the evidence provided by the guidelines, an author conducted a post-hoc research of the evidence available in literature from 2009 to 2014 in order to obtain an elaborate updated. He considered randomized controlled trials, meta-analyses and reviews, excluding case reports and case series.

On completion of the guideline evidence regarding $\mathrm{CD}$, an analysis was done on PubMed, and randomized controlled trials (RCT) and systematic reviews were selected from publications from 2013 to 2015 in the English language, satisfying the MESH term celiac disease.

New data on CD were found concerning the epidemiology, and the role of specific agents on the CD trigger, like drugs and intestinal microbiota. The analy- 
sis also focused on the discussion about the best work up for the study of mineral metabolism alterations induced by $\mathrm{CD}$. We report the results on new drugs for disease control and the underlining concepts of the recent NICE guidelines, edit up to September 2015.

\section{The management of patients with celiac disease: results}

Through the databases, we identified and selected 9 guidelines. ${ }^{2-4,91-96}$

The overall quality of selected guidelines was assessed by 5 authors using the AGREE II instrument. The evaluation results are shown in Table 4.-4,91-95

The Guidelines ACG Clinical Guidelines: Diagnosis and Management of Celiac Disease - 2013² were those, assessed by us; they had the greatest overall score, so they were the reference guidelines for the preparation of this monograph. They were judged as adoptable in $100 \%$ of cases by the group, but with modifications for 3 evaluators.

\section{Celiac disease: post hoc analysis}

As regards the role of environmental factors on $\mathrm{CD}$ expression, in genetically predisposed children, two large European RCT (Prevent CD and CELIPREV) did not find a significant reduction in the incidence of the disease development with the change of the timing introduction of gluten in the weaning. However, a late introduction was associated with a delay of the disease onset. ${ }^{97}$ Breastfeeding did not have any protective effect. ${ }^{98}$

Other environmental factors probably could con-

Table 4. Summary of the scores of evaluators selected on the guidelines for celiac disease for the different sizes according to the AGREE instrument II.

\begin{tabular}{|c|c|c|c|c|c|c|c|}
\hline \multirow[t]{2}{*}{ Guidelines } & $\begin{array}{l}\text { Dimension } 1 \\
\text { Goals and } \\
\text { motivations }\end{array}$ & $\begin{array}{l}\text { Dimension } 2 \\
\text { Stakeholder } \\
\text { involvement }\end{array}$ & $\begin{array}{c}\text { Dimension } 3 \\
\text { Methodological } \\
\text { rigor }\end{array}$ & $\begin{array}{l}\text { Dimension } 4 \\
\text { Clarity in the } \\
\text { exposition }\end{array}$ & $\begin{array}{l}\text { Dimension } 5 \\
\text { Applicability }\end{array}$ & $\begin{array}{c}\text { Dimension } 6 \\
\text { Editorial } \\
\text { independence }\end{array}$ & $\begin{array}{c}\text { Overall } \\
\text { (adoptable } \\
\text { or not) }\end{array}$ \\
\hline & \multicolumn{7}{|c|}{ Total score and percentage } \\
\hline $\begin{array}{l}\text { ACG Clinical Guidelines: } \\
\text { Diagnosis and Management } \\
\text { of Celiac Disease - } 2013^{2}\end{array}$ & $\begin{array}{l}102 / 105 \\
94.57 \%\end{array}$ & $\begin{array}{l}66 / 105 \\
56.7 \%\end{array}$ & $\begin{array}{c}177 / 245 \\
67.9 \%\end{array}$ & $\begin{array}{l}101 / 105 \\
95.6 \%\end{array}$ & $\begin{array}{c}92 / 140 \\
60 \%\end{array}$ & $\begin{array}{c}61 / 70 \\
85 \%\end{array}$ & $\begin{array}{c}\text { Adoptable in all } \\
\text { cases - in } 3 / 5 \\
\text { with modifications }\end{array}$ \\
\hline $\begin{array}{l}\text { World Gastroenterology } \\
\text { Organization Global } \\
\text { Guidelines - } 2013^{4}\end{array}$ & $\begin{array}{l}92 / 105 \\
85.6 \%\end{array}$ & $\begin{array}{c}78 / 105 \\
70 \%\end{array}$ & $\begin{array}{c}166 / 245 \\
62.4 \%\end{array}$ & $\begin{array}{l}83 / 105 \\
75.5 \%\end{array}$ & $\begin{array}{c}117 / 140 \\
80.8 \%\end{array}$ & $\begin{array}{c}55 / 70 \\
75 \%\end{array}$ & $\begin{array}{l}\text { Adoptable in } 80 \% \\
\text { cases - in } 2 / 5 \\
\text { with modifications }\end{array}$ \\
\hline $\begin{array}{l}\text { European Society for } \\
\text { Pediatric Gastroenterology, } \\
\text { Hepatology, and Nutrition } \\
\text { Guidelines for the Diagnosis } \\
\text { of Celiac Disease } 2012^{3}\end{array}$ & $\begin{array}{l}98 / 105 \\
92.2 \%\end{array}$ & $\begin{array}{l}95 / 105 \\
88.9 \%\end{array}$ & $\begin{array}{c}191 / 245 \\
90.9 \%\end{array}$ & $\begin{array}{c}96 / 105 \\
90 \%\end{array}$ & $\begin{array}{c}80 / 140 \\
50 \%\end{array}$ & $\begin{array}{c}60 / 70 \\
83.3 \%\end{array}$ & $\begin{array}{c}\text { Adoptable in all } \\
\text { cases - in } 2 / 5 \\
\text { with modifications }\end{array}$ \\
\hline $\begin{array}{l}\text { Diagnosis and management } \\
\text { of adult coeliac disease: } \\
\text { guidelines from the British } \\
\text { Society of Gastroenterology } \\
2014^{91}\end{array}$ & $\begin{array}{l}77 / 105 \\
85.6 \%\end{array}$ & $\begin{array}{l}75 / 105 \\
83.3 \%\end{array}$ & $\begin{array}{c}229 / 245 \\
92.3 \%\end{array}$ & $\begin{array}{c}96 / 105 \\
90 \%\end{array}$ & $\begin{array}{c}116 / 140 \\
80 \%\end{array}$ & $\begin{array}{c}45 / 70 \\
75 \%\end{array}$ & $\begin{array}{c}\text { Adoptable in all } \\
\text { cases - in } 1 / 5 \\
\text { with modifications }\end{array}$ \\
\hline $\begin{array}{l}\text { A Summary of the } \\
\text { NASPGHAN } \\
\text { Guidelines } 2010^{92}\end{array}$ & $\begin{array}{l}46 / 105 \\
34.4 \%\end{array}$ & $\begin{array}{l}32 / 105 \\
18.9 \%\end{array}$ & $\begin{array}{l}62 / 245 \\
12.8 \%\end{array}$ & $\begin{array}{l}58 / 105 \\
47.8 \%\end{array}$ & $\begin{array}{l}51 / 140 \\
25.8 \%\end{array}$ & $\begin{array}{c}18 / 70 \\
13.3 \%\end{array}$ & $\begin{array}{c}\text { Not adoptable } \\
\text { in all cases }\end{array}$ \\
\hline $\begin{array}{l}\text { Joint BSPGHAN and Coeliac } \\
\text { UK guidelines for the } \\
\text { diagnosis and management } \\
\text { of celiac disease in children } \\
2013^{93}\end{array}$ & $\begin{array}{l}70 / 105 \\
77.7 \%\end{array}$ & $\begin{array}{l}57 / 105 \\
63.3 \%\end{array}$ & $\begin{array}{l}83 / 245 \\
39.5 \%\end{array}$ & $\begin{array}{l}77 / 105 \\
85.5 \%\end{array}$ & $\begin{array}{l}50 / 140 \\
41.6 \%\end{array}$ & $\begin{array}{l}46 / 70 \\
76.7 \%\end{array}$ & $\begin{array}{c}\text { Adoptable in } 60 \% \\
\text { of cases - in } 2 / 5 \\
\text { with modifications }\end{array}$ \\
\hline $\begin{array}{l}\text { Coeliac disease - Recognition } \\
\text { and assessment of coeliac } \\
\text { disease NICE - } 2009^{94}\end{array}$ & $\begin{array}{c}101 / 105 \\
95.6 \%\end{array}$ & $\begin{array}{l}88 / 105 \\
81.1 \%\end{array}$ & $\begin{array}{c}245 / 245 \\
100 \%\end{array}$ & $\begin{array}{l}90 / 105 \\
83.3 \%\end{array}$ & $\begin{array}{c}115 / 140 \\
79.2 \%\end{array}$ & $\begin{array}{c}66 / 70 \\
93.3 \%\end{array}$ & $\begin{array}{c}\text { Adoptable in all } \\
\text { cases - in } 1 / 5 \\
\text { with modifications }\end{array}$ \\
\hline Guidelines AIC $2008^{95}$ & $\begin{array}{c}61 / 105 \\
51 \%\end{array}$ & $\begin{array}{l}39 / 105 \\
26.7 \%\end{array}$ & $\begin{array}{c}77 / 245 \\
20 \%\end{array}$ & $\begin{array}{l}64 / 105 \\
54.4 \%\end{array}$ & $\begin{array}{l}64 / 140 \\
36.7 \%\end{array}$ & $\begin{array}{c}22 / 70 \\
20 \%\end{array}$ & $\begin{array}{l}\text { Adoptable in } 20 \% \\
\text { of cases but } \\
\text { with modifications }\end{array}$ \\
\hline Guidelines AIC $2008^{96}$ & $\begin{array}{l}53 / 105 \\
42.2 \%\end{array}$ & $\begin{array}{l}38 / 105 \\
25.6 \%\end{array}$ & $\begin{array}{c}58 / 245 \\
11 \%\end{array}$ & $\begin{array}{l}66 / 105 \\
56.7 \%\end{array}$ & $\begin{array}{l}47 / 145 \\
21.6 \%\end{array}$ & $\begin{array}{l}20 / 70 \\
16.7 \%\end{array}$ & $\begin{array}{c}\text { Adoptable in } 20 \% \\
\text { of cases }\end{array}$ \\
\hline
\end{tabular}


tribute to a significant increase in $\mathrm{CD}$ incidence (by a factor of 4-5 times in the last 5 years) such as cesarean section, perinatal and childhood infections, the use of certain drugs and processed wheat flour. ${ }^{99}$

Concerning the role of certain drugs in the development of CD, a large population-based case-control study conducted in Sweden, showed a strong association between the exposure to antisecretory medications (PPI) and a subsequent diagnosis of celiac disease [odds ratio (OR) 4.79; 95\% confidence interval (CI) 4.17-5.51], suggesting a causal relationship. It was assumed that the rise of gastric $\mathrm{pH}$ levels and the increase of gastric mucosal permeability due to PPI therapy, can compromise the peptic digestion and the mucosal absorption of food antigens, contributing to the development of the gluten-triggered autoimmunity that characterizes $\mathrm{CD} .{ }^{100} \mathrm{~A}$ bias of this study was the inclusion of all patients that had taken PPI for symptoms of CD itself.

Another large population-based case-control study demonstrated a positive association (OR 1.30 CI 95\%) between antibiotic use and CD development, suggesting that the iatrogenic dysbiosis can cause an alteration of the intestinal microbiota and a subsequent modification of its known immunological effects. ${ }^{101}$

At present, intestinal microbiota is being studied for a crucial role in the pathogenesis of different diseases, including CD. The microbiota profile differs between celiac and non-celiac patients. In particular in CD patients, Bacteroides and Escherichia coli species resulted prominent while Bifidobacteria and Lactobacilli species, known to exert protection from gliadin damage on intestinal wall, were reduced. ${ }^{102}$

Corazza et al. suggest promptly starting the osteoporosis treatment in the $\mathrm{CD}$ forms with clear malabsorption and in the subjects who have passed a peak bone mass age, with silent disease or without symptoms, if there are additional risk factors for the alteration of the bone metabolism. Subjects with silent or asymptomatic disease that do not reach the age of peak bone mass should be first submitted to bone densitometry. ${ }^{103}$

A recent Swedish study on population has found a larger risk of lymphoproliferative disorders (OR 2.25, 1.18-4.34) and of bone fractures in subjects affected by $\mathrm{CD}$ with persistent villi atrophy, despite a glutenfree $\operatorname{diet}(43 \%$ of subjects: no. 3317$) .{ }^{104}$ However, differences have not been demonstrated in global mortality, cardiovascular outcomes, obstetric complications in pregnant women. ${ }^{104}$

In two studies in phase II of Larazotide and ALV003, two drugs studied as supplements of a gluten-free diet, showed a partially effective result, demonstrating that the factors involved in the pathogenic cascade of $\mathrm{CD}$ are many and therefore the drugs for specific targets are less efficient.

Larazotide acetate is a membrane protector as it re- duces permeability and consequently the symptoms related to CD. It is an oral intake peptide that antagonizes the action of zonulin, a transmembrane protein involved in the transport of gliadin. The drug prevents tight junction opening then it can reduce gluten uptake and the associated sequelae due to the immune response activation. In two randomized trials ( 270 patients), Larazoide $v s$ placebo, there was no significant difference in changes of the intestinal permeability but the group with Larazotide recorded a significant decline in TTG levels and a significant reduction in the symptoms. ${ }^{105}$

ALV003 is a combination of endopeptidase and endoprotease, for oral intake, which improves the gluten degradation into non-toxic peptides. Celiac subjects that assumed ALV003 in a phase II randomized study, reported minor mucosal damage (assessed at the height of the villi of the intestinal biopsy) despite a placebo group. ${ }^{106}$

Finally, recent NICE guidelines emphasize the appropriateness of serological tests for TTG with certified kit, the need for the laboratories to define a suitable protocol for finding EMA antibodies, as channeling blood samples in experienced centers or starting specific internal training. The lack of evidence on the management of bone metabolism alterations and a defined follow-up program were also emphasized. ${ }^{107}$

\section{References}

1. Merese B, Malamut G, Cerf-Bensussan N. Celiac disease: an immunological jigsaw. Immunity 2012;36:907-19.

2. Rubio-Tapia A, Hill ID, Kelly CP, et al. ACG clinical guidelines: diagnosis and management of celiac disease. Am J Gastroenterol 2013;108:656-76.

3. Husby S, Koletzko S, Zimmer KP, et al. ESPGHAN Working Group on Coeliac Disease Diagnosis; ESPGHAN Gastroenterology Committee; European Society for Pediatric Gastroenterology, Hepatology and Nutrition. Hepatology and nutrition guidelines for the diagnosis of coeliac disease. J Pediatric Gastroenterol Nutr 2012;54:136-60.

4. Van Heel DA, West J. Recent advances in coeliac disease. Gut 2006;55:1037-46.

5. Bai JC, Fried M, Corazza GR, et al. World gastroenterology organisation global guidelines on celiac disease. J Clin Gastroenterol 2013;47:121-6.

6. Not T, Horvath K, Fasano A, et al. Celiac disease risk in the USA: high prevalence of antiendomysium antibodies in healthy blood donors. Scand J Gastroenterol 1998;33: 494-8.

7. Abadie V, Barriero LB, Jabri B. Integration of genetic and immunologic insights into a model of celiac disease pathogenesis. Annu Rev Immunol 2011;29:493-525.

8. Sollid LM. Coeliac disease: dissecting a complex inflammatory disorder. Nat Rev Immunol 2002; 2:647-55.

9. Jansen MA, Van der Zwet KV, Moll HA, et al. Herpes virus infections and transglutaminase type 2 antibody positivity in childhood: the generation R study. J Pediatr Gastroenterol Nutr 2016 [Epub ahead of print]. 
10. Green PH, Jabri B. Coeliac disease. Lancet 2003;362: 383-91.

11. Jabri B, Sollid LM. Tissue-mediated control of immunopathology in coleliac disease. Nat Rev Immunol 2009;9:858-70.

12. Harrison's. Kasper DL, Braunwald E, Hauser S. Harrison's principles of internal medicine. 16th Ed. New York, USA: McGraw-Hill Medical Publishing Division; 2005.

13. Cammarota G, Cuoco L, Gasbarrini G, et al. Onset of coeliac disease during treatment with interferon for chronic hepatitis C. Lancet 2000;356:1494-5.

14. Gerdes AM, Horder M, Bonnevie-Nielsen V. Increased IFN- $\alpha$-induced sensitivity but reduced reactivity of 2,5oligoadenylate synthetase (2,5AS) in trisomy 21 blood lymphocytes. Clin Exp Immunol 1993;93:93-6.

15. Troncone R, Auricchio S. Rotavirus and celiac disease: clues to the pathogenesis and perspectives on prevention. J Pediatr Gastroenterol Nutr 2007;44:527-8.

16. Stene LC, Hoffenberg EJ, Haas JE, et al. Rotavirus infection frequency and risk of celiac disease autoimmunity in early childhood: a longitudinal study. Am J Gastroenterol 2006;101:2333-40.

17. Nistal E, Herran AR, Casquiero J, et al. Study of duodenal bacterial communities by 16 sr rna gene analysis in adults with active celiac disease versus non celiac disease controls. J Appl Microbiol 2016 [Epub ahead of print].

18. Marasco G, Schiumarini R, Colecchia A, et al. Gut microbiota and celiac disease. Dig Dis Sci 2016 [Epub ahead of print].

19. Mustalahti K, Sulkanen S, Holopainem P, et al. Celiac disease among healthy members of multiple case coeliac disease families. Scand J Gastroenterol 2002;37:161-5.

20. Ludvigsson JF, Leffler DA, Bai JC, et al. The Oslo definitions for coeliac disease and related terms. Gut 2013;62:43-52.

21. Hammer ST, Greenson JK. The clinical significance of duodenal lymphocytosis with normal villus architecture. Arch Pathol Lab Med 2013;137:1216-9.

22. Volta U, Granito A, Fiorini E, et al. Usefulness of antibodies to deamidated gliadin peptides in celiac disease diagnosis and follow-up. Dig Dis Sci 2008;53:1582-8.

23. Korponay-Szabo IR, Dahlbom I, Laurila K, et al. Elevation of IgG antibodies against tissue transglutaminase as a diagnostic tool for coeliac disease in selective IgA deficiency. Gut 2003;52:1567-7.

24. Berger R, Schmidt G. Evaluation of six anti-gliadin antibody assays. J Immunol Methods 1996;191:7786.

25. Leffler DA, Schuppan D. Update on serologic testing in celiac disease. Am J Gastroenterol 2010;105:2520-4.

26. Hoffemberg EJ, MacKenzie T, Barriga, et al. A prospective study of the incidence of childhood celiac disease. J Pediatr 2003;143:308-14.

27. Volta U. La sierologia: utilità e significato dei test anticorpali. In: Volta U, Ubaldi E, eds. La malattia celiaca in medicina generale. Pisa: Pacini Editore; 2009. pp 16-9.

28. Rashtak S, Ettore MW, Homburger HA, et al. Comparative usefulness of deamidated gliadin antibodies in the diagnosis of celiac disease. Clin Gastroenterol Hepatol 2008;6:462-532.

29. Collin P, Kaukinen K, Vogelsang H, et al. Antiendomysial and antihuman recombinant tissue transglutaminase antibodies in the diagnosis of coeliac disease: a biopsy-proven European multicentre study. Eur J Gastroenterol Hepatol 2005; 17:85-91.

30. Hopper AD, Cross SS, Hurlstone DP, et al. Pre-endoscopy serological testing for coeliac disease: evaluation of a clinical decision tool. BMJ 2007;334:729.

31. Dickey W, Hughes DF, McMillan SA. Reliance on serum endomysial antibody testing underestimates the true prevalence of coeliac disease by one fifth. Scad J Gastroenterol 2000;35:181-3.

32. Rosekrans PC, Meijer CJ, Polanco I, et al. Long-term morphological and immunohistochemical observations on biopsy specimens of small intestine from children with gluten sensitive enteropathy. J Clin Pathol 1981;34:138-44.

33. Clemente MG, De Virgilis S, Fasano A, et al. Early effects of gliadin on enterocyte intracellular signalling involved in intestinal barrier function. Gut 2003;52:218-23.

34. Smecuol E, Bai JC. Diagnosis of celiac disease. World Gastroenterol News E-EGN 2011;16:7-10.

35. Marsh MN. Gluten major histocompatibility complex and the small intestine. Gastroenterology 1992;102:330-54.

36. Ciclitira PJ. Celiac disease: a techinical review. Gastroentetology 2001;120:1526-40.

37. Sperandeo MP, Tosco A, Izzo V, et al. Potential celiac patients: a model of celiac disease pathogenesis. PLoS One 2011;6:e21281.

38. Auricchio R, Tosco A, Piccolo E, et al. Potential celiac children: 9-year follow-up on a gluten-containing diet. J Gastroenterol 2014;109:913-21.

39. Volta U, Mumolo MG, Caio G, et al. Autoimmune enteropathy: not all flat mucosa mean coeliac disease. Gastroenterol Hepatol Bed Bench 2016;9:140-5.

40. Marsh MN, Crowe PT. Morphology of the mucosal lesion in gluten sensitivity. Baillières Clin Gastroenterol 1995;9:273-93.

41. Obberhuber G, Granditsch G, Vogelsang H. The histopathology of celiac disease: time for a standardized report scheme for pathologists. Eur J Gastroenterol Hepatol 1999;11:1185-94.

42. Antonioli DA. Celiac disease: a progress report. Mod Pathol 2003;16:342-6.

43. Sollid LM, Thorsby E. HLA susceptibility genes in celiac disease: genetic mapping and role in pathogenesis. Gastroenterology 1993;105:910-22.

44. Abadie V, Sollid L, Barriero LB, et al. Integration of genetic and immunological insights into a model of celiac disease pathogenesis. Annu Rev Immunol 2011;29:493-525.

45. Rokkas T, Niv Y. The role of video capsule endoscopy in the diagnosis of celiac disease: a meta-analysis. Eur J Gastroenterol Hepatol 2012;24:303-8.

46. Lebwohl B, Kapel RC, Neugut AI, et al. Adherence to biopsy guidelines increases celiac disease diagnosis. Gastrointest Endosc 2011;74:103-9.

47. Catassi C, Elli L, Bonaz B, et al. Diagnosis of non-celiac gluten sensitivity (NCGS): the Salerno Experts' Criteria. Nutrients 2015;7:4966-77.

48. Lebwohl B, Ludvigsson JF, Green PHR. Celiac disease and non-celiac gluten sensitivity. BMJ 2015;351:h4347.

49. Volta U, Bardella MT, Calabrò A, et al. An Italian prospective multicenter survey on patients suspected of having non-celiac gluten sensitivity. BMC Med 2014;12:85.

50. Lundin KE, Alaedini A. Non-celiac gluten sensitivity. Gastrointest Endosc Clin N Am 2012;22:723-34. 
51. Al-Toma WHM, Hadithi VM, Von Blomberg BME, Mulder CJJ. Survival in refractory coeliac disease and enteropathy-associated T-cell lymphoma: retrospective evaluation of single-centre experience. Gut 2007;56: 1373-8.

52. Rubio-Tapia A, Kelly DG, Lahr BD, et al. Clinical staging and survival in refractory celiac disease: a single center experience. Gastroenterology 2009; 136 (1): 99-107.

53. Bardella MT, Fredella C, Prampolini L, et al. Body composition and dietary intakes in adult celiac disease patients consuming a strict gluten-free diet. Am J Clin Nutr 2000;72:937-9.

54. Akobeng AK, Thomas AG. Systematic review: tolerable amount of gluten for people with coeliac disease. Aliment Pharmacol Ther 2008;1:1044-52.

55. Ansaldi N, Tavassoli K, Faussone D, et al. Clinico-histological behavior of celiac patients after gluten load following the definitive diagnosis. Pediatr Med Chir 1988;10:3-6.

56. Ludvigsson JF. Mortality and malignancy in celiac disease. Gastrointest Endosc Clin Nam 2012;22:705-22.

57. Kemppainen T, Kroger H, Janatuinen E, et al. Osteoporosis in adult patients with celiac disease. Bone 1999;24:249-55

58. West J, Logan RF, Card TR, et al. Fracture risk in people with celiac disease: a population- based cohort study. Gastroenterology 2003;125:429-36.

59. Choi JM, Lebwohl B, Wang J, et al. Increased prevalence of celiac disease in patients with unexplained infertility in the United States. J Reprod Med 2011;56:199-203.

60. Norgard B, Fonager K, Sorensen HT, et al. Birth outcomes of women with celiac disease: a nation wide historical cohort study. Am J Gastroenterol 1999;94: 2435-40.

61. Ludvigsson JF, Montgomery SM, Ekbom A. Celiac disease and risk of adverse fetal outcome: a populationbased cohort study. Gastroenterology 2005;129:454-63.

62. Khashan AS, Henriksen TB, Mortensen PB, et al. The impact of maternal celiac disease on birth weight and preterm birth: a Danish population-based cohort study. Hum Reprod 2010;25:528-34.

63. Abdulkarim AS, Burgart LJ, See J, et al. Etiology of non responsive celiac disease: results of a systematic approach. Am J Gatroenterolog 2002;97:2016-21.

64. Leffler DA, Dennis M, Hyett B, et al. Etiologies and predictors of diagnosis in nonresponsive celiac disease. Clin Gastroenterol Hepatol 2007;5:445-50.

65. O’Mahony S, Howdle PD, Losowsky MS. Review article: management of patients with non-responsive coeliac disease. Aliment Pharmacol Ther 1996;10:671-80.

66. Fine KD, Meyer RL, Lee EL. The prevalence and causes of chronic diarrhea in patients with celiac sprue treated with a gluten-free diet. Gastroenterology 1997;112:1830-8.

67. Roshan B, Leffler DA, Jamma S, et al. The incidence and clinical spectrum of refractory celiac disease in a North American referral center. Am J Gastroenterol 2011;106:923-8.

68. Ho-Yen C, Chang F, van der Walt J, et al. Recent advances in refractory coeliac disease: a review. Histopathology 2009;54:783-95.

69. Trier JS, Falchuk ZM, Carey MC, et al. Celiac sprue and refractory sprue. Gastroenterology 1978;75:307-16.

70. Gale J, Simmonds PD, Mead GM, et al. Enteropathy- type intestinal T-cell lymphoma: clinical features and treatment of 31 patients in a single center. J Clin Oncol 2000;18:795-803.

71. Van de Water J, Cillessen S, Visser O, et al. Enteropathy associated T-cell lymphoma and its precursor lesions. Best Pract Res 2010;24:43-56.

72. Wahab PJ, Meijer JW, Mulder CJ. Histologic follow-up of people with celiac disease on a gluten-free diet: slow and incomplete recovery. Am J Clin Pathol 2002;118: 459-63.

73. Malamut G, Afchain P, Verkarre V, et al. Presentation and long-term follow-up of refractory celiac disease: comparison of type I with type II. Gastroenterology 2009;136:81-90.

74. Woodward J. Improving outcomes of refractory celiac disease - current and emerging treatment strategies. Clin Exp Gastroenterol 2016;9:225-36.

75. Cellier C, Delabesse E, Helmer C, et al. Refractory sprue, coeliac disease, and enteropathy-associated T-cell lymphoma. French Coeliac Disease Study Group. Lancet 2000;356:203-8.

76. Tursi A, Brandimarte G, Giorgetti G. High prevalence of small intestinal bacterial overgrowth in celiac patients with persistence of gastrointestinal symptoms after gluten withdrawal. Am J Gastroenterol 2003;98:839-43.

77. Pallav K, Leffler DA, Tariq S, et al. Non coeliac enteropathy: the differential diagnosis of villous atrophy in contemporary clinical practice. Aliment Pharmacol Ther 2012;35:380-90.

78. Cellier C, Patey N, Mauvieux L, et al. Abnormal intestinal intraepithelial lymphocytes in refractory sprue. Gastroenterology 1998;114:471-81.

79. Daum S, Weiss D, Hummel M, et al. Frequency of clonal intraepithelial T lymphocyte proliferations in enteropathy-type intestinal T cell lymphoma, coeliac disease and refractory sprue. Gut 2001;49:804-12.

80. Gerrard JW, Ross CA, Smellie JM. Coeliac disease: results of late treatment with gluten-free wheat diet. Lancet 1955;268:587-9.

81. Malamut G, Meresse B, Cellier C, et al. Refractory celiac disease: from bench to bedside. Semin Immunopathol 2010;34:601-13.

82. Rubio-Tapia A, Murray J. Classification and management of refractory coeliac disease. Gut 2010;59:547-57.

83. Goerres MS, Meijer JWR, Wahab PJ, et al. Azathioprine and prednisone combination therapy in refractory coeliac disease. Aliment Pharm Ther 2003;18:487-94.

84. Robak T, Wierzbowska A, Robak E. Recent clinical trials of cladribine in hematological malignancies and autoimmune disorders. Rev Recent Clin Trials 2006;1:15-34.

85. Ministero della Sanità. Decreto ministeriale. Regolamento di istituzione della rete nazionale delle malattie rare e di esenzione dalla partecipazione al costo delle relative prestazioni sanitarie ai sensi dell'articolo 5 , comma 1, lettera b) del decreto legislativo 29 aprile 1998, n. 124. In: Gazzetta Ufficiale, 12/07/2001, n. 160, Supplemento Ordinario n. 180/L.

86. García-Manzanares A, Lucendo AJ. Nutritional and dietary aspects of celiac disease. Nutr Clin Pract 2011; 26:163.

87. Ministero della Sanità. Decreto ministeriale. Assistenza sanitaria integrativa relativa ai prodotti destinati ad una alimentazione particolare. D.M 8 giugno 2001. In: Gazzetta Ufficiale n. 157, 05/07/2001. 
88. Ministero della Sanità. Rete nazionale di presidi sanitari e centri interregionali di riferimento per la prevenzione, la sorveglianza, la diagnosi e la terapia delle malattie rare; 2001. Available from: http://www.salute.gov.it/ imgs/C_17_dossier_22_listaFile_itemName_0_file.pdf

89. Presidenza del Consiglio dei Ministri. Accordo, ai sensi dellarticolo 4, del decreto legislativo 28 agosto 1997, n. 281, tra il Governo, le regioni e le province autonome di Trento e di Bolzano sul "Protocollo per la diagnosi e il follow up della celiachia". Proceedings della Conferenza Permanente per i rapporti tra lo Stato, le Regioni e le Province autonome di Trento e Bolzano, 30 luglio 2015. Available from: http://www.statoregioni.it/Documenti/DOC 048313 125\%20CSR\%20PUNTO\%209\% 20ODG.pdf

90. AGREE Next Step Consortium. AGREE II. Checklist per valutare la qualità delle linee guida. Bologna: Fondazione GIMBE; Aprile 2011.

91. Ludvigson J, Bai J, Biagi F, et al. Diagnosis and management of adult coeliac disease: guidelines from the British Society of Gastroenterology. Gut 2014;63:1210-28.

92. North American Society for Pediatric Gastroenterology, Hepatology and Nutrition (NASPGHAN). Diagnosis and treatment of celiac disease in children: clinical practice guideline summary; 2010. Available from: http://www.naspghan.org/content/51/en/professionaleducation/resources/celiac-disease

93. Murch S, Jenkins H, Auth M, et al. Joint BSPGHAN and Coeliac UK guidelines for the diagnosis and management of celiac disease in children. Arch Dis Child 2013; 98:806-11.

94. National Institute for Health and Care Excellence (NICE). Coeliac disease: recognition and assessment. NICE guidelines [CG86]; Published date: May 2009. Available from: https://www.nice.org.uk/guidance/ $\operatorname{cg} 86$ ?unlid=50950412420166601429

95. Associazione Italiana Celiachia (Aic). Linee guida celiachia valutazione morfologica; 2008. Available from: http://www.celiachia.it/Aic/AIC.aspx?SS=351\&M=867

96. Linee Ministero della Salute - Comitato Nazionale Sicurezza Alimentare (C.N.S.A.) - Consulta Scientifica Per La Sicurezza Alimentare; Associazione Italiana Celiachia (AIC). Linee guida per la diagnosi ed il monitoraggio della celiachia e relative patologie associate e complicanze (a cura del Comitato Scientifico Nazionale dell'AIC). Edizione 2009. supplemento ordinario alla In: G.U. suppl. ord., 7/2/2008, ser. gen. n. 32. Available from: http://www.celiachia.it/aic/res/doc/lineee_guida_ followup_it.pdf

97. Lionetti E, Castellaneta S, Francavilla R, et al. Introduction of gluten, HLA status, and the risk of celiac disease in children. N Engl J Med 2014;371:1295-303.

98. Vriezinga SL, Auricchio R, Bravi E, et al. Randomized feeding intervention in infants at high risk for celiac disease. N Engl J Med 2014;371:1304-15.

99. Ludvigsson JF, Green PH. The missing environmental factor in celiac disease. N Engl J Med 2014;371:1341-3.

100. Lebwohl B, Spechler SJ, Wang TC, et al. Use of proton pump inhibitors and subsequent risk of celiac disease. Dig Liver Dis 2014;46:36-40.

101. Marild K, Lebwohl B, Green PH, et al. Antibiotic exposure and the development of coeliac disease: a nation wide case-control study. BMC Gastroenterol 2013; 13:109.

102. De Sousa, Moraes LF, Gouveia Peluzio Mdo C, et al. Intestinal microbiota and probiotics in celiac disease. Clin Microbiol Rev 2014;27:482-9.

103. Di Stefano M, Megoli C, Corazza R, et al. Bone mass and mineral metabolism alterations in adult celiac disease: pathophysiology and clinical approach. Nutriens 2013;5:4786-99.

104. Lebwohl B, Murray JA, Rubio-Tapia A, et al. Predictors of persistent villous atrophy in celiac disease: a population-based study. Aliment Pharmacol Ther 2014;39: 488-95.

105. Kelly CP, Green PH, Murray JA, et al. Larazotide acetate in patients with coeliac disease undergoing a gluten challenge: a randomised placebo-controlled study. Aliment Pharmacol Ther 2013; 37:252-62.

106. Lahdeaho ML, Kaukinen K, Laurila K, et al. Glutenase ALV003 attenuates gluten-induced mucosal injury in patients with celiac disease. Gastroenterology 2014; 146:1649-58.

107. National Institute for Health and Care Excellence (NICE). Coeliac disease: recognition, assessment and management. NICE guidelines [NG20]; Published date: September 2015. Available from: https://www.nice.org. uk/guidance/ng20 